\title{
The Image of Geolandscape Representations in the Ornamental Culture of the Evens and the Evenks of Yakutia
}

\author{
Galina N. Varavina* \\ Institute for Humanities Research \\ and Indigenous Studies of the North SB RAS \\ 1 Petrovskogo Str., Yakutsk, 677027, Russia
}

Received 12.01.2018, received in revised form 11.04.2018, accepted 14.04.2018

Based on the ethnographic and field data in the context of the semiotic approach and the geospatial theory, the article analyzes the ornamental culture of the northern Tungus, namely the Evens and the Evenks. It is shown that ethno-local models of the northern landscape are represented through visual-imagery perception (art, ornamentation). An ornament is considered a symbolic "language" associated with a wide range of "texts" - beliefs and rituals. It acts as a special kind of the "language" of the world outlook, a mental worldview and the culture of the ethnos. The ornamental language of the Evens and the Evenks acts as a symbolic formation, where the symbols of Nature, Mother Earth, fertility, the symbolism of the ancestral tree ("unity of the genus"), water, fire, the symbol of the cyclic life and a spatial code function.

Keywords: Yakutia, the Evens, the Evenks, northern nomads, world outlook, ornamental culture, geospatial images, sign-symbol, semantics of ornament, mental worldview, cultural heritage.

DOI: 10.17516/1997-1370-0261.

Research area: ethnography, ethnology and anthropology.

The ornament for the northern peoples is a kind of sign system, partly replacing the writing and accompanying each person throughout his life from birth to death. The imaginative "language" of the ornament is rich and multifaceted, incorporating the experience of human interaction with nature. The Tunguska ornament is one of the phenomena of the national culture of the Evens and the Evenks, reflecting its diversity and specific features. The specificity of the Tunguska ornament is that it is an expression of their nomadic culture, a traditional way of life and a unique worldview. It is distinguished by its artistic-stylistic features and sacred-semantic content. Ornamental motifs of the Evens and the Evenks were considered sacred; they were called to perform the functions of an amulet. In general, their traditional ornament is in many ways very close to each other both in material and in motives. It is used to decorate various household items, clothing, handbags, pockets, rugs, cradles, reindeer harness, objects of birch bark, bones,

(C) Siberian Federal University. All rights reserved

* Corresponding author E-mail address: varavina1982@mail.ru 
wood and metal. Ornamental motifs are strictly geometric in character. The welt is particularly loved. In the opinion of S.V. Ivanov, "images of any animals as part of the patterns do not occur" (Ivanov, 1963: 251).

The predominant ornamental motifs of the Evens and the Evenks are strips (ornamental motifs in the form of strips and lines), various circular ornament (simple and concentric circles, semicircles, circles with a dot), rectangles, squares, triangles, rhombuses, etc.

Strips, lines are the simplest forms of geometric ornamentation, which received considerable development from the Tungus. In general, this kind of ornament was and is very widespread in all groups of the Evens and the Evenks of Yakutia. The ornament consisting of zoned strips, which could be up to thirty, was and is very common as well. It is made in a different way: it is embroidered with deer hair and colored threads, laid out from colored beads, and also painted on the rovduga. Narrow strips can be combined with wide ones. Clothes, especially the women's breastplate, were and are decorated in a very abundant way (AFD, 2010; 2013).

The strips and lines in a different variant and combination, of course, belong to a very ancient common foundation of geometric motifs. S.V. Ivanov attributed this ornament "to the northeastern and partly to the North Asian type", which is represented by various geometric motifs of the simplest outlines (straight lines, strips, etc.). All these motives are part of the welts. In the opinion of S.V. Ivanov, "the patterns of this type of ornament are very ancient", as well as various circular ornament. "They have many analogies in the art of the peoples of the Far North-East, on the one hand, and in the ornamentation of the Baikal Neolithic on the other hand" (Ivanov, 1963: 312).

The names of patterns and motifs of various ornaments of the Evens of Yakutia in the form of strips and lines are particularly worth noticing.
For example, innatach khereche is a wide strip consisting of two rows of white and red wool of a spring elk mane, part of the apron ornament. It is interesting to note that "this pattern depicts the track of an elk, a wild deer, a big horn and shows that the men in this family are lucky hunters (the hair of the elk mane is painted red with ulyk grass that grows on the seashore)" (The colors of the northern lights in the patterns of the masters..., 2004: 19). Kukui, which is a motif of a beaded ornament, is a black strip of skin, painted with homemade dark-colored paint, which is obtained by mixing black ash from a burnt tamnik with glue welded from the black hooves of a deer. Kiarika is a motif of a beaded ornament, "showing that a person since a young age works with deer and loves them" (The colors of the northern lights in the patterns of the masters..., 2004: 161). Nil'gicha is a motif of an ornament in the form of a white strip of specially treated suede, cleared from wool by special moisturizing (sorologon). It is interesting to note that "this pattern denotes the way of life in childhood". Nulenedetin is a piece of an ornament in the form of a strip of red cloth, "signifies the rainbow of life" (Robbek, 2004: 213). In our opinion, this name comes from the word nulene: red, pink, ruddy; scarlet, pink color; blush. Hamcha is beaded lines, consisting of alternating black and white beads on the edge or middle of the embroidery. It is interesting to note that these lines "signify good and bad periods of life". Khin'chacha is the motif of the ornament on the black leather with slits uncovering a white strip of leather. Churilan is an ornament of 2 blue, 1 red, 3 white rows of beads, again 2 blue, 1 red, then 5 mendelen against the background of the deveche (Robbek, 2004: 336). Evdech is an ornament of 2-3 rows of blue, dark blue or green beads. It is interesting to note that "rows of blue and dark blue beads mean that a person led a nomadic life. There was always the blue sky 
above him" (The colors of the northern lights in the patterns of the masters..., 2004: 23).

It is important to note that stripes and lines symbolized the road, the movement, the person's life path ("path", road, track). A straight line means "a direct path", "a direct trace". As one of the basic semantic components of the archaic worldview of the Evens and the Evenks is the mythologem "road". The road corresponds with the life path, the "path" of the human soul into the afterlife and is semantically allocated in transitional rituals. The choice of the road in the wedding ceremonies, as well as in the performance of the funeral ritual (the road to the cemetery and back was correlated with the afterlife of the deceased) was of great importance.

Equally common is the ornament from various circles (various embroidered and beaded circles), occupying a very prominent place in the traditional art of the Evens and the Evenks. The circular ornament, elements of a circle (simple and concentric circles, semicircles, circles with a dot) are known from ancient times to almost all indigenous peoples of Siberia and the North. These patterns were interpreted by them as signs of the sun, and also they were seen as images of other heavenly bodies. It is important to note that circles (as well as strips), concentric circles and circles with a dot in the center "serve as the main ethnic delimiter of the Tungusic art culture" (Kocheshkov, 1997: 71).

According to scientists, the circular ornament, as a whole a group of patterns, including points, circles with a dot, concentric circles and semicircles "could have appeared at the end of the Neolithic era, but developed and took shape in the era of metal" (Ivanov, 1963: 274). S.V. Ivanov attributed this ornament "to the North Asian type". He wrote that there are sufficient grounds to see "an ancient group of motifs that existed in part already in the Neolithic time in the Baikal region" in this type (Ivanov, 1963: 312).

The Evens and the Evenks decorated and decorate welts and flaps of clothes, deer headrests, handbags, pouches, etc. with different circular ornaments forming belts. Fur clothes, bibs and shoes were decorated as welts. Gloves, bags and hatswere decorated as individual large circles. Beaded circles were most often white, black and blue, sometimes red. A circle in the Even language is called merety: 1) circle; 2) round); merety kaltakan, merety gadan semicircle (Cincius; Riches, 1957: 131). An ornament, a pattern consisting of circles is called meretikegche (embroidered from beads) (Robbek, 2004: 182). Ogete (or ogeltekegche) is an ornament very similar to meretikegche (circles). At the same time circles are joined in the figure-eight. This ornament is used to decorate any part of the costume.

According to our informant, the circular ornament is very widespread among the Tiugiasirsky Evens. "One of them is called tileregchel and means the sun or the lake." According to her, this ornament can also mean "fish eyes" and is a guard against evil spirits (AFD, 2016).

The circle occupied an important place in the mythological worldview of the northern nomads, including the Evens and the Evenks, and was one of the dominant symbols in the traditional art of these peoples. As is known, the symbolism of the circle has a complex semantics. The circle is a universal symbol, containing the original perfection, sacredness, infinity, eternity. It symbolizes dynamism, endless movement, as well as return, return movement. The circle means integrity, unity, continuity and cyclicity of a person's life. It is connected with the life circle and soul of man. Besides, the circle means the sign of the sun and other heavenly bodies. The circle as an image of the sun in the ornament of 
the northern Tungus represents prosperity, wealth and strength. It is interesting to note that the Evens of Yakutia had amulets for the newborn, which symbolized the human soul. These included the image of the sun in the form of a magic circle sewn to the back of the cradle's back. This image symbolized the very soul of the child. It was made with a multicolored bead - white, blue and dark blue. This amulet defended the child's soul, helped it to "get stronger", "get used to" the body of the newborn, and become a full-fledged person, a full member of the family (AFD, 2010; 2013). In general, the circular ornament in clothing, especially in the ritual, personified the vital force of man and performed the functions of an amulet. It is important to note that the circular ornament was often applied on the front of clothing. Such round metal disks as a motif of the "sun" were also sewn mostly on the front of clothing. They were a kind of protective and patrimonial signs that served as a charm amulet. It is interesting to note that the Yakuts considered the silver circle "myohaxma" on the headdress of the bride as an amulet from the influence of evil spirit, which personified the life force of a girl.

In general, rows of round metal discs, stamped silver plaques located on ceremonial clothes, were one of the elements of ornamentation (the motif of the "sun") and were considered symbols of fertility, prosperity of future generations. It is important to note that round plaques and beads embroidered in several rows formed a kind of "fence", "barrier", "hedge" ("toguruchchu kharyskhallaakh"). This "hedge" "defended" the human soul as an impenetrable shield from the influence of evil spirits, and so on.

Besides, a group of motifs in the form of rectangles, squares and rhombuses, forming vertical and horizontal bands is a common ornament among the Evens and the Evenks of Yakutia. Simple and complex arcuate patterns (arcs with diamonds, crosses) and triangles also belong to the number of common ornamental motifs. Based on the materials of S.V. Ivanov, the northeastern and partly North Asian types of ornaments are represented by geometric motifs in various forms such as rhombuses, squares and rectangles, as well as zigzags, angles, triangles, chevrons, spurs, etc. These ornaments, like many simplest patterns, had a wide geography of distribution. All these motives are part of welts. In the opinion of S.V. Ivanov, the patterns of this type of ornament are very ancient. "They have many analogies in the art of the peoples of the Far North-East, on the one hand, and in the ornamentation of the Baikal Neolithic on the other hand" (Ivanov, 1963: 313).

Triangle is a universal geometric figure. S.V. Ivanov attributed the triangle "to the northeastern and partly to the North Asian type" of ornaments (Ivanov, 1963: 313). The symbolism of this figure is closely connected with man for many peoples. In the cultures of many peoples, including Siberia and the North, the triangle was a symbol of fertility, feminine fertility, as it symbolized the womb, the feminine. It is important to note that many ancient ornaments often include triangles as a symbol of mountains. A significant role in this is played by the existing geometric symbolism of the Cosmos, in which all the round forms correspond with the sky, the square with the earth, and the triangle (fire, stone on the top) acts as a symbol of aspiration to the mountain space and the connection between the terrestrial and celestial worlds.

According to our informants, who are Lamynkhinsky (Kobiai district) and Tugiasirsky (Even-Bytantai district) Evens, patterns in the form of a triangle (as well as an arched ornament) in ornamentation means mountains, a symbol of mountains (AFD, 2013; 2015). An ornament in the form of an arc is the symbol of a mountain for the Tiugiasirsky Evens. "The ornamental motif in the form of a triangle and an arc acts 
as a symbol of mountains, ascent, aspiration to the mountain space and the connection of the earthly and heavenly worlds" (AFD, 2013; 2015). As is known, the mythological functions of the mountain are diverse. The mountain acts as the most common variant of the transformation of the World Tree. The mountain is often perceived as an image of the world, a model of the universe. The mountain is the center of the world, it is a landmark. The Evens of Yakutia had a veneration of the sacred mountains. According to their ideas, spirits-patrons lived there; on the whole the divine characters were connected with the top of the mountain. It is important to note that the mountain, the taiga and the river are the main symbols of the sacred geography for the northern nomads. Thus, the mountain taiga Evens (the Lamunkhinsky and Tiugiasirsky groups of Evens) have a common ornament - a group of motifs in the form of simple and complex arcuate patterns and triangles that represent the symbolism of the mountain. A widespread wavy pattern of the Evens and the Evenks of Yakutia symbolizes the river, the movement of water.

According to our informant, the Tiugiasirsky Evens call an ornament in the form of a triangle diukagcha, which means mountains, and also ilumu, which is, a house, a dwelling. According to her, this ornament has the symbolics of the mountain, and also this sign blesses the prosperity of the family. "This ornament is a business card, which attests to the origin of the northern family". Besides, the ornament in the form of a triangle with circles at the top indicates mountains and the sun and is distributed mainly among mountain taiga Evens (AFD, 2016). Utekegche ("houses") is an ornament resembling a triangular shape, from the Even uten: a dugout, a hut, a shanty, a hovel, a dwelling (Cincius; Riches, 1957: 207). Utekegche is the motif of a beaded ornament of the shape of half-diamonds, outside only with one strip of white beads, inside - blue half-diamonds alternate with black beads (Cincius; Riches, 1957: 274). This ornament is mainly used to decorate the lower part of the clothing - aprons, as well as soft boots made of deer skins and caftan tails. The color scheme is a dark line on a light background (for example, black on blue) or light on a dark background (white on a black background), sometimes black and white lines are located side by side.

The Evens of Yakutia call an ornament resembling a triangular shape kokchalikagcha (kokchalikcha). It is one of the most common decorative motifs. Kokchilikagcha is an ornament of white and black beads, forming a broken line, which has a triangle of blue or dark blue beads inside called chuktin. It is interesting to note that "this ornament indicates that the person had many relatives, children, grandchildren" (The colors of the northern lights in the patterns of the masters..., 2004: 20). Kokchalikagcha, which is the motif of beaded ornament, is a pattern consisting of pointed peaks. It is embroidered with beads - black between two whites, between them are blue or dark blue beads (Robbek, 2004: 144). This ornament is mostly used to decorate soft boots made of deer skins, aprons, used in finishing caftans. The ornamental sign chuktin is a triangle of blue beads between the patterns depicting the head and shoulders of the fox (The colors of the northern lights in the patterns of the masters..., 2004: 23).

The ornament in the form of a diamond, a square and a rectangle is very widely distributed among the Evens of Yakutia: nil'gicha khin'chacha is alternating black and white rectangles; such a stripe comes from a wide white stripe, through long vertical slits of which a stripe of black rovduga with a width equal to the slits goes (Robbek, 2004: 193). Tominuka is alternating white and black rectangles from summer deer skins. It is interesting to note that this ornament means "that at the beginning 
of life a man had many deer" (Robbek, 2004: 251). Tokrinde is a wide strip of rectangles of different sizes from black and white skins, which are interspersed with brown squares from deveche. In general, this is the alternation of 4 white, 3 black strips and a square of deveche. It is interesting to note that "this ornament means the life path of a man, a successful hunter, who had many deer for all his life" (Paints of the Northern Lights in the patterns of the masters..., 2004: 22). In our opinion, this name could have come from the Even word "toki" - moose, elk. Hin'chacha is a strip of rectangles of a black and white rovduga (chessboard pattern) alternating through slits (Paints of the Northern Lights in the patterns of the masters..., 2004: 23). According to our informant, the ornament in the form of a chessboard is widely distributed among the Tiugiasirsky and Lamunkhinsky Evens and denotes the continuous flow of life, the change of day and night. Besides, it can "mean grazing white and black deer and shows the status of a rich man" (AFD, 2016). Konkeche is the motif of the ornament of sticks of dark and light fur diamonds, alternating in a checkerboard pattern. Konkechegche is a pattern in the form of diamonds, embroidered with beads (Robbek, 2004: 182). It is interesting to note that the diamond as a universal symbol of fertility is associated with the ideas of the Foremother, which was conceived as a whole as Mother Nature. The ornament in the form of a diamond can be a guardian and a symbol of happy offspring (AFD, 2013; 2015).

Thus, the ornamental culture of the Evens and the Evenks of Yakutia is rich and multifaceted, it retains an original character. The ornament, as an integral part of the objective world, was included in the symbolic field of culture. It performed the connecting role between the material and spiritual world and gave a status to a subject, as well as various functions (for example, security one). A protective role in the Even and Evenk ornamentation was played by the symbolism of color. The ornament can be considered as a symbolic "language" associated with a wide range of "texts" - beliefs and rituals. It acts as a special kind of the "language" of the world outlook, the traditional culture of the people. Thus, ethno-local models of the northern landscape are represented through visual-imagery perception (art, ornamentation). The ornamental language acts as a symbolic formation, where the symbols of Nature, Mother Earth, fertility, the symbolism of the ancestral tree ("unity of the genus"), water, fire, the symbol of the cyclic life and a spatial code function.

\section{References}

AFD (2010). In Polevye materialy avtora, sobrannye v Allaikhovskom raione Iakutii v $2010 \mathrm{~g}$. [The author's field data, collected in Allaihovsky district of Yakutia in 2010].

AFD (2013). In Polevye materialy avtora, sobrannye v Kobiaiskom raione Iakutii v $2013 \mathrm{~g}$. [The author's field data, collected in Kobiai district of Yakutia in 2013].

AFD (2015). In Polevye materialy avtora, sobrannye v Verkhoianskom raione Iakutii v $2015 \mathrm{~g}$. [The author's field data, collected in Verkhoyansk district of Yakutia in 2015].

AFD (2016). In Interv'iu s Nikulinoi Zinaidoi Platonovnoi, evenka iz Eveno-Bytantaiskogo raiona Jakutii [Interview with Nikulina Zinaida Platonovna, an Evenk female from the Eveno-Bytantai District of Yakutia].

Cincius, V.I., Rishes, L.D. (1957). Evensko-russkii slovar' [The Even-Russian Dictionary]. Leningrad, Uchpedgiz, $276 \mathrm{p}$.

Ivanov, S.V. (1963). Ornament narodov Sibiri kak istoricheskii istochnik (po materialam XIXnachala XX v.). Narody Severa i Dal'nego Vostoka [Ornament of the peoples of Siberia as a historical 
source (based on the materials of the $19^{\text {th }}$ - early $20^{\text {th }}$ century). The peoples of the North and the Far East]. Moscow; Leningrad Publishing House of the Academy of Sciences of the USSR, 442 p.

Kocheshkov, N.V. (1997). Tiurko-mongoly i tunguso-man'chzhury. Problemy istoriko-kul'turnykh sviazei na materiale narodnogo dekorativnogo iskusstva XIX-XXvv. [Turkic-Mongols and TungusManchus. Problems of historical and cultural ties on the basis of folk decorative art of the $19^{\text {th }}-20^{\text {th }}$ centuries]. SPb, Nauka, $176 \mathrm{p}$.

Robbek, M.E. (2004). Kraski severnogo siianiia v uzorakh masterits: (Prikladnoe iskusstvo evenov Berezovki) [Paints of the Northern Lights in the patterns of the masters: (Applied art of the Evens of Berezovka)], In Pamiatniki etnicheskoi kul'tury korennykh malochislennykh narodov Severa, Sibiri i Dal'nego Vostoka [Monuments of ethnic culture of indigenous minorities of the North, Siberia and the Far East], 4. Novosibirsk, Nauka, 88 p.

Robbek, V.A., Robbek, M.E. (2004). Evensko-russkii slovar' [The Even-Russian Dictionary], In Pamiatniki etnicheskoi kul'tury korennykh malochislennykh narodov Severa, Sibiri i Dal'nego Vostoka [Monuments of ethnic culture of indigenous minorities of the North, Siberia and the Far East], 6. Novosibirsk, Nauka, $356 \mathrm{p}$.

\section{Образ геоландшафтных представлений}

\section{в орнаментальной культуре эвенов и эвенков}

\section{Якутии}

Г.Н. Варавина

Институт гуманитарных исследований и проблем малочисленных народов Севера СО РАН Россия, 677027, Якутск, ул. Петровского, 1

В статье на основе этнографических и полевых материалов в контексте семиотического подхода и геопространственной теории анализируется орнаментальная культура северных тунгусов - эвенов и эвенков. Показано, что через визуально-образное восприятие (искусство, орнамент) репрезентируются этнолокальные модели северного ландшафта. Орнамент считается как символический «язык», связанный с широким кругом «текстов»-верований и ритуалов. Он выступает как особый род «языка» мировоззрения, ментальной картины мира и культуры этноса. Орнаментальный язык эвенов и эвенков выступает в качестве знакового образования, где функиионируют символика Природы, Матери-Земли, плодородия, символика родового дерева («единство рода»), воды, огня, символ иикличности жизни, а также пространственный код.

Ключевые слова: Якутия, эвены, эвенки, северные кочевники, мировоззрение, орнаментальная культура, геопространственные образы, знак-символ, семантика орнамента, ментальная картина мира, культурное наследие.

Научная специальность: 07.00.07 - этнография, этнология и антропология. 